\title{
Pengendalian Efektif sebagai Cara Akuisisi Teritorial: Analisis Kasus Sipadan - Ligitan
}

\author{
Effective Occupation as Method of Territorial Acquisition: Analysis of \\ Sipadan - Ligitan Case
}

\begin{abstract}
Marcel Hendrapati ${ }^{1}$, Marthen Napang ${ }^{1}$, Syamsuddin Mochtar ${ }^{2}$, Yudhariksawan ${ }^{1}$

${ }^{1}$ Bagian Hukum Internasional, Fakultas Hukum, Universitas Hasanuddin Jln. Perintis Kemerdekaan Km. 10, Tamalanrea, Makassar, Sulawesi Selatan, 90245, Indonesia. Tel./Fax:+62-411587219 E-mail: mhendrapati@yahoo.com

${ }^{2}$ Bagian Hukum Pidana, Fakultas Hukum, Universitas Hasanuddin

Jln. Perintis Kemerdekaan Km. 10, Tamalanrea, Makassar, Sulawesi Selatan, 90245, Indonesia. Tel./Fax: +62-411587219E-mail: syamsuddinmuchtar@yahoo.com
\end{abstract}

Submitted: Jun 17, 2015; Reviewed: Jul 26, 2015; Accepted: Aug 5, 2015

\begin{abstract}
Various ways, such as cession, prescription, discovery to acquire a title to a part of territory can be conducted by any state, provided this state can exercise effective occupation of the territory. Occupation (or taking of possession) which has already been going for a long time, continuous and peaceful followed with recognition is not of physical character merely, but particularly relates to a display of state functions constituting a manifestation of teritorial souvereignty, as it can be discovered through many judicial and arbitral decisions, like the Sipadan - Ligitan Case. Creation of Malaysia's title to the two islets is related not only with principle of effective occupation, but also with an existing great difficulty to do avoidance of external influence behind the International Court of Justice (ICJ) decision. Any arguments and considerations of the court densely contain alibi or artificial play of tongue aimed at protecting economic interest of certain state in Malaysia in such a way that dissenting opinion and separate opinion emerge of which the resource is any unworthiness or injustice.
\end{abstract}

Keywords: Effective Occupation; International Court of Justice, Teritorial Souvereignty

\begin{abstract}
Abstrak: Berbagai cara seperti cession, prescription, discovery dalam memperoleh hak atas suatu wilayah dapat dilakukan oleh suatu negara, asal saja negara tersebut dapat menjalankan pengendalian efektif (effective occupation) atas wilayah itu. Pengendalian yang berlangsung lama, terus menerus dan damai yang disertai dengan pengakuan tidak memiliki karakter fisik semata-mata, tetapi terutama terkait dengan pelaksanaan fungsi-fungsi pemerintahan sebagai manifestasi kedaulatan teritorial, sebagaimana ditemukan melalui berbagai yurisprudensi, seperti kasus Sipadan - Ligitan. Hak Malaysia atas kedua pulau itu tidak semata-mata terkait prinsip 'effective occupation', tetapi juga terkait dengan sulitnya menghindari pengaruh eksternal di balik putusan Mahkamah Internasional. Argumentasi dan pertimbangan mahkamah sarat dengan alibi atau permainan kata dalam mematahkan pendirian pihak Indonesia sehingga dirasakan adanya ketidakadilan.
\end{abstract}

Kata Kunci: Kedaulatan Teritorial; Mahkamah Internasional; Pengendalian Efektif 


\section{PENDAHULUAN}

Keputusan Mahkamah Internasional (International Court of Justice/ICJ) yang memenangkan negeri tetangga atas Indonesia dalam sengketa Sipadan-Ligitan didasarkan atas alasan pengendalian dan penguasaan efektif (effective occupation). Negeri tetangga berhasil dalam menjaga kelestarian lingkungan pada kedua pulau yang dipersengketakan sebagai pelaksanaan fungsi administrasi pemerintahan negeri tersebut. Prinsip 'effective occupation' yang digunakan Mahkamah bukan sesuatu yang baru sebab sebelumnya prinsip seperti ini sudah sering digunakan oleh lembaga penyelesaian sengketa internasional yang menangani berbagai sengketa teritorial.

Kasus Pulau Palmas (Pulau Miangas) yang melibatkan Amerika Serikat dan Belanda pada tahun 1906 yang diselesaikan melalui arbitrasi menerapkan apa yang disebut pengendalian atau penguasaan efektif, di mana pemerintah Hindia Belanda berhasil membuktikan terselenggaranya fungsi administrasi pemerintahan secara terus menerus dan damai, ${ }^{1}$ dan hal ini menunjukkan terjadinya pengendalian efektif yang menciptakan hak (title) bagi Belanda atas pulau tersebut.

Pelaksanaan fungsi administrasi pemerintahan adalah perwujudan kedaulatan teritorial Hindia Belanda atas pulau Palmas. Dalam melaksanakan fungsi administrasi pemerintahan atas pulau warisan pemerintah kolonial, maka pemerintah Indonesia men-

1 J.G. Starke (1984), Introduction to International Law (London: Butterworths, pp.153-154; Ian Brownlie (1979), Principles of Public International Law, Oxford: Oxford University Press, p.132. etapkan pulau Palmas sebagai titik pangkal untuk penarikan garis pangkal kepulauan Indonesia dengan menerbitkan UndangUndang Nomor 4/Prp Tahun 1960. Penetapannya sebagai titik pangkal berdasarkan undang-undang ini menunjukkan berjalannya fungsi adminitrasi pemerintahan dalam rangka melakukan pengendalian efektif (effective occupation) atas pulau Palmas.

Kasus 'Clipperton Island' yang dipersengketakan melalui arbitrasi internasional antara Perancis dan Meksiko pada akhir abad ke-19. Arbitrasi menyatakan bahwa Perancis berhak atas pulau tersebut karena negara ini ternyata mampu melakukan pengendalian dan penguasaan efektif atas Clipperton Island. Meksiko menyatakan haknya atas pulau Clipperton dengan alasan pulau tersebut ditemukan pertama kalinya oleh Spanyol yang pernah menjajah wilayah Meksiko sebelum negeri ini mendapat kemerdekaannya. Akan tetapi hak yang didasarkan atas penemuan tidak disertai dengan pelaksanaan kedaulatan teritorial secara nyata dan efektif atas pulau Clipperton yang dipersengketakan. Sebaliknya, Perancis hanya melakukan semacam proklamasi dan memasang bendera nasionalnya dalam menyatakan hak kepemilikannya atas pulau tersebut. Namun demikian, bagi arbitrasi tindakan proklamasi dan pemasangan bendera di pulau tersebut diakui sebagai suatu cara atau bentuk penguasaan efektif sehingga Perancis dinyatakan selaku pemilik kedaulatan teritorial atas Clipperton Island yang terletak di Samudera Pasifik . ${ }^{2}$

2 Ibid, pp.148-149; David H. Ott. (1987). Public International Law in the Modern World, London: Pitman Publishing, p.117. 
'The Permanent Court' dalam kasus 'the Eastern Greenland case' mempertimbangkan status daerah yang dipersengketakan pada tanggal yang dianggap krusial, yaitu 10 Juli 1931 ketika Norwegia memproklamirkan pendudukannya atas daerah itu. Norwegia menegaskan daerah itu adalah tanah tidak bertuan (terra nullius). Sedangkan pihak Denmark berpendapat bahwa haknya atas daerah itu sudah ada sejak lama, atas dasar terlaksananya secara nyata kekuasaan Negara atas seluruh daerah Greenlandia.

Mahkamah membuat keputusan yang menguntungkan Denmark, di mana Mahkamah memperhatikan pola kegiatan yang terjadi antara 1721 dan 1931, termasuk penegakan peraturan perundang-undangan yang menetapkan adanya monopoli negara dalam bidang perdagangan, pemberian izin perdagangan, pertambangan, dan konsesi-konsesi lain, pelaksanaan fungsi-fungsi dan administrasi pemerintahan, dan membuat banyak perjanjian yang menegaskan hak-hak Denmark atas Greenlandia. Okupasi yang dilakukan Norwegia adalah illegal atau tidak sah karena sebelum Norwegia melakukan okupasi atau penguasaan atas wilayah Greenland, Denmark setidak-tidaknya selama 10 tahun telah menjalankan hak-hak kedaulatannya atas daerah yang cukup luas sehingga tercipta hak kedaulatan bagi Denmark secara sah.

Sesuai dengan Statuta ICJ keputusan Mahkamah Internasional terkait sengketa pulau Sipadan-Ligitan sudah final dan mengikat. Bahkan sebelum Indonesia dan Malaysia maju ke ICJ, kedua negara telah membuat perjanjian khusus untuk menerima apapun putusan dari mahkamah. Namun banyak kalangan merasa kecewa atas sikap dan langkah yang diambil oleh otoritas terkait karena dianggap tidak optimal dalam perjuangan untuk membela berbagai aktivitas pengendalian efektif yang telah dilakukan baik pada masa kolonial maupun setelah kemerdekaan. Timbulnya perasaan kecewa dan kesal dari berbagai elemen bangsa disebabkan bukan semata-mata akibat kekalahan di forum ICJ, melainkan juga dan terutama kurang optimalnya pemerintah dalam memelihara warisan kedaulatan Hindia Belanda. Padahal kedua pulau tersebut sebenarnya sudah berada di bawah penguasaan atau pengendalian Hindia Belanda berdasarkan bukti historis-yuridis dan bukti fisik yang terdapat di pulau Sipadan.

Berlakunya perjanjian yang dinamakan Konvensi London 1891 (the London Convention) yang menentukan alokasi kedaulatan antara Inggeris dan Hindia Belanda, kegiatan kapal perang HMS Lynx yang beroperasi untuk mencegah dan memberantas aksi kejahatan perompakan (piracy) yang sering terjadi di perairan Laut Sulawesi, termasuk di perairan sekitar pulau Sipadan dan pulau Ligitan menghadirkan adanya fakta historis yuridis yang menunjukkan hak kepemilikan Nederland dan Indonesia atas kedua pulau itu $^{3}$. Sedangkan mengenai bukti-bukti fisik dapat diketahui dari adanya tulisan dalam bahasa Belanda yang tertera pada sebuah tugu di pulau Sipadan. Walaupun tulisan berbahasa Belanda telah dihilangkan oleh Malaysia pada waktu timbulnya sengketa,

\footnotetext{
International Court of Justice. (2002). Sovereignty over Pulau Ligitan and Pulau Sipadan (Indonesia/ Malaysia), Judgment of 17 December 2002, ICJ Reports, p. 625.
} 
namun hal ini sudah terdokumentasi. ${ }^{4}$

Namun berbagai pertimbangan mahkamah yang tidak jarang bersifat artifisial seakan-akan menimbulkan provokasi yang mengarah pada pemikiran yang sulit terhindarkan. Kesulitan mengelakkan hadirnya pemikiran untuk tidak semata-mata melihat putusan dan pertimbangan mahkamah tahun 2002 sebagai sesuatu yang bersifat yuridis saja, tetapi juga sebagai sesuatu yang secara tersirat dimaksudkan untuk melindungi adanya kepentingan-kepentingan tertentu di negara tetangga Indonesia.

Beranjak dari uraian latar belakang permasalahan di atas, maka dirumuskan 3 (tiga) fokus kajian dalam tulisan ini: Pertama, cara-cara seperti apa yang dapat digunakan oleh suatu Negara dalam memperoleh hak atas suatu wilayah? Kedua, mengapa prinsip effective occupation yang diajukan oleh Malaysia dalam kasus Sipadan-Ligitan dapat dibenarkan oleh Mahkamah Internasional? Ketiga, apakah putusan ICJ yang memberi kemenangan kepada Malaysia dalam kasus Sipadan-Ligitan semata-mata didasarkan atas prinsip effective occupation?

\section{METODE}

Penelitian atas permasalahan yang telah dirumuskan di atas adalah merupakan penelitian hukum normatif yang dimaksudkan untuk mengidentifikasi konsep, gagasan dan asas-asas hukum dalam menelaah dan mengkaji prinsip pengendalian efektif (effective occupation) dalam memperoleh hak teritorial: Analisis atas kasus SipadanLigitan.

4 Kompas (2002), Kedaulatan atas Sipadan dan Ligitan diberikan kepada Malaysia, bukan Indonesia, hlm.15.
Penelitian hukum yang sifatnya normatif pada dasarnya dilakukan melalui studi kepustakaan (library research) dengan tujuan untuk mengumpulkan data-data (dalam hal ini data-data sekunder) yang terdapat di Universitas Hasanuddin, Makassar. Di samping itu, bahan-bahan hukum diperoleh melalui instansi pemerintah di Jakarta dan melalui jaringan internet.

Teknik pengumpulan data atau bahan hukum dalam penelitian ini dilakukan dengan melakukan inventarisasi dokumen melalui studi pustaka dan studi lapangan. Studi pustaka adalah cara mencari bahan hukum atau data dengan mengkaji dokumen hukum, berupa buku-buku, referensi, literatur hukum, jurnal hukum dan peraturan perundang-undangan terkait yang mencakup: (a) bahan hukum primer; (b) bahan hukum sekunder; dan (c) bahan hukum tersier. Data yang diperoleh dari penelitian lapangan adalah data primer tentang segala sesuatu yang ada kaitannya dengan aspek hukum dari prinsip 'effective occupation' dalam menyelesaikan sengketa kedaulatan teritorial. Adapun teknik pengumpulan data dalam penelitian lapangan dilakukan melalui wawancara dengan pejabat instansi pemerintah.

Metode analisis yang digunakan adalah metode kualitatif, yaitu dengan menganalisis isi ketentuan hukum yang berkaitan dengan objek kajian. Langkah-langkah analisis bahan hukum dilakukan melalui beberapa tahapan, seperti bahan hukum yang dikumpulkan disistematisasi, yaitu ditata dan disesuaikan dengan obyek yang diteliti, kemudian bahan yang sudah disistematisasi diungkapkan atau diuraikan dan dijelaskan sesuai dengan obyek yang diteliti dengan menerapkan teori, 
dan akhirnya bahan yang telah dijelaskankan dievaluasi, yaitu dinilai dengan menggunakan ukuran ketentuan-ketentuan hukum yang berlaku.

\section{ANALISIS DAN PEMBAHASAN}

\section{Latar Belakang Persengketaan atas Pulau}

\section{Ligitan dan Pulau Sipadan}

Munculnya pertama kali sengketa wilayah Indonesia-Malaysia di Laut Sulawesi atas kepemilikan Pulau Sipadan dan Pulau Ligitan telah ditempuh melalui berbagai macam cara penyelesaian dengan mengutamakan persahabatan antara kedua Negara guna mencari pemecahan yang seadil-adilnya. ${ }^{5}$

Masalah itu sendiri timbul pada tahun 1969 ketika delegasi kedua Negara mengadakan pertemuan untuk menetapkan garis batas landas kontinen masing-masing negara. Pada saat itu kedua delegasi sepakat untuk tidak membicarakan masalah kepemilikan Pulau Sipadan dan Pulau Ligitan karena di samping pembicaraan mengenai kedua pulau itu bisa mengeruhkan suasana damai pascakonfrontasi di antara kedua Negara, juga adanya kepekaan politik saat itu terkait tuntutan Filipina atas Sabah sehingga kedua pihak sepakat membiarkan kedua pulau itu dalam posisi status quo.

Setelah masalah ini didiamkan dan berjalan selama satu dasawarsa, Pemerintah Indonesia pada 8 Februari 1980 menyampaikan nota protes kepada Pemerintah Malaysia karena pada bulan Desember 1979 Malaysia menerbitkan peta yang memasukkan kedua pulau itu ke dalam wilayahnya. Bahkan

\footnotetext{
S.M. Noor (2008), Politik Hukum dalam Praktek Ratifikasi di Indonesia. (Disertasi). Makassar: Program Pascasarjana Universitas Hasanuddin, hlm.202 - 210 .
}

Presiden Soeharto pun segera menemui Perdana Menteri Husain Onn yang disusul dengan pertemuan tingkat Menteri. Nota protes dari pihak Indonesia dan nota balasan dari pihak Malaysia tidak terelakkan sehingga kedua Negara membentuk suatu kelompok kerja yang disebut 'Joint Working Group on Pulau Sipadan and Pulau Ligitan' guna menyelesaikan sengketa kepemilikan atas kedua pulau itu. ${ }^{6}$

Kelompok kerjasama tersebut telah mengadakan beberapa kali pertemuan. Pertemuan pertama dilakukan di Jakarta pada bulan Juli tahun 1992, di mana Indonesia menegaskan posisinya mengenai kepemilikan atas kedua pulau itu dengan menyampaikan argumentasi hukum dan beberapa dokumen serta peta untuk mendukung klaimnya atas kedua pulau itu. Demikian pula Malaysia telah menyerahkan sebuah Memorandum Pemerintahnya disertai dokumen pendukungnya, kemudian terjadi tukar menukar dokumen, tetapi belum dibahas substansinya ${ }^{7}$.

Pertemuan kedua diselenggarakan di Kuala Lumpur pada bulan Januari tahun 1994, di mana hasilnya dapat dikatakan relatif sama dengan pertemuan pertama. Namun tercapai kemajuan yang ditandai dengan adanya kesepakatan untuk mempercepat proses penyelesaian sengketa kepemilikan atas kedua pulau tersebut, yakni dengan mengadakan pertemuan lanjutan di Indonesia. Kemajuan hasil pertemuan ini mencerminkan amanat hasil pertemuan Presiden Soeharto dengan Perdana Menteri Mahathir Muhammad di Pulau Langkawi pada bulan Juli 1992 bahwa sengketa kedua pulau itu 
perlu segera diselesaikan agar tidak membebani generasi mendatang. ${ }^{8}$

Kemajuan lain selama putaran kedua adalah dikeluarkannya pernyataan pers bersama yang menyebutkan kedua delegasi menyampaikan sejumlah dokumen untuk menegaskan posisi masing-masing. Di samping itu kedua delegasi menyepakati sejumlah prinsip, antara lain bahwa masalah Sipadan dan Ligitan akan diselesaikan dengan prinsip-prinsip hukum internasional, termasuk perjanjian yang relevan, konvensi-konvensi dan berbagai saling pe-ngertian yang melibatkan pihak yang relevan dan waktu yang relevan pula. Selanjutnya di-nyatakan bahwa suatu penyelesaian segera atas masalah sengketa Pulau Sipadan dan Pulau Ligitan akan berdampak positif bagi hubungan persahabatan dan bertetangga kedua Negara. Terakhir, penyelesaian sengketa ini harus melalui konsultasi dan atau melalui cara damai.

Putaran ketiga perundingan penyelesaian sengketa atas kedua pulau itu diadakan di Jakarta pada bulan September 1994. Malaysia berkeinginan untuk segera menyelesaikan sengketa tersebut dengan melibatkan pihak ketiga. Malaysia mengajak Indonesia untuk menyelesaikan sengketa Pulau Sipadan dan Pulau Ligitan di depan ICJ karena ICJ sebagai pihak ketiga dipandang mampu menyelesaikan isu tersebut secara berwibawa, netral, aman dan sesegera mungkin. Sebaliknya pihak Indonesia dalam pidato penutupan Kelompok Kerjasama putaran ketiga ini oleh Ketua delegasinya menyatakan bahwa Indonesia belum merasa perlu melibatkan pihak ketiga. Namun apabila kelak memang harus

8 Ibid. demikian, Indonesia memilih Dewan Tinggi (High Council) ASEAN sebagai pihak ketiga.

Malaysia menolak menggunakan 'High Council' dalam menyelesaikan sengketa tersebut karena Negara itu khawatir mekanisme seperti itu akan banyak menghabiskan waktu. Pihak Malaysia tidak menghendaki penyelesaiannya berlarut-larut sebab bisa mengganggu hubungan baik kedua Negara. Sedangkan alasan Indonesia memilih 'ASEAN High Council' apabila memang sudah dibutuhkan pihak ketiga, yaitu karena lembaga itu tentu saja memiliki pengetahuan yang lebih baik mengenai masalah yang terjadi di kawasan ASEAN.

Negosiasi dan diplomasi yang telah dilakukan oleh kedua Negara selama bertahuntahun tidak menghasilkan solusi mengenai kepemilkan atas kedua pulau tersebut. Tidak tercapainya titik temu soal penyelesaian sengketa Sipadan dan Ligitan menyebabkan pada tahun 1994 Presiden Soeharto dan Perdana Menteri Mahathir Mohammad sepakat untuk mengangkat Wakil Pribadi (Special Representative) guna menyelesaikan masalah tersebut. Presiden Soeharto menunjuk Mensesneg Moerdiono, sedangkan PM Mahathir Mohammad menunjuk Wakil PM Anwar Ibrahim. Kedua Wakil Pribadi itu mengadakan empat kali pertemuan di Kuala Lumpur dan Jakarta, tetapi keduanya tidak berhasil mencapai kesepakatan. ${ }^{9}$

Lewat pertemuan mereka di Kuala Lumpur pada 21 Juni 1996, Moerdiono dan Anwar Ibrahim menandatangani laporan bersama yang diajukan kepada Presiden Soeharto dan PM Mahathir Mohammad yang

$9 \quad$ Ibid, hlm.210. 
isinya merekomendasikan agar sengketa soal Sipadan dan Ligitan dibawa ke Mahkamah Internasional. Ternyata rekomendasi itu diterima oleh kedua Kepala Pemerintahan.

Tanggal 31 Mei 1997 Malaysia dan Indonesia secara resmi memulai proses penentuan klaim kepemilikan atas Pulau Ligitan dan Pulau Sipadan dengan menyerahkannya kepada Mahkamah Internasional. Perjanjian khusus untuk secara bersama-sama menyerahkan pertikaian kedaulatan atas kedua pulau itu kepada Mahkamah Internasional ditandatangani oleh Menlu RI Ali Alatas dan Menlu Malaysia Abdullah Ahmad Badawi di Kuala Lumpur menjelang pertemuan informal para Menlu ASEAN. Sebelum diajukan secara resmi kepada Mahkamah Internasional, perjanjian khusus (special agreement) itu harus terlebih dahulu diratifikasi oleh parlemen masing-masing Negara. Setelah diratifikasi, kedua pihak akan bertemu lagi untuk menentukan tanggal penyerahan kasus itu kepada Mahkamah Internasional. Ternyata kedua pihak menyatakan apapun hasil keputusan Mahkamah Internasional nanti akan bersifat final dan mengikat. ${ }^{10}$

\section{Berbagai Cara Akuisisi Teritorial}

Akuisisi wilayah (acquisition of territory) adalah singkatan dari akuisisi kedaulatan teritorial (acquisition of sovereignty over territory). ${ }^{11}$ Kedaulatan teritorial berarti hak

10 DPR-RI memberikan persetujuan kepada Pemerintah untuk melakukan ratifikasi perjanjian Indonesia dan Malaysia untuk berperkara di depan Mahkamah Internasional pada 31 Desember 1997. Lihat, Arif Havas Oegroseno (2009), "Status Hukum Pulau-Pulau Terluar Indonesia", Indonesian Journal of International Law, 6(3): 308-320.

11 Malcolm N. Shaw (1986), International Law, Cambridge: Grotius Publications Limited, p.238 $-239$. untuk menjalankan fungsi-fungsi Negara di wilayah tersebut, sehingga mengenyampingkan Negara-negara lain dalam menjalankan fungsi-fungsi Negara atau pemerintahan. Ada berbagai cara untuk melakukan akuisisi atau memperoleh suatu wilayah. Melalui pendekatan tradisional dikenal berbagai cara akuisisi yang berakar dari hukum Romawi terkait kepemilikan atas tanah (property), dan hal ini tidak mengherankan karena kedaulatan atas wilayah atau kedaulatan teritorial menyerupai kepemilikan atas tanah.

Pada abad 16 dan 17 saat lahirnya hukum internasional modern, maka teori monarki absolut cenderung menganggap wilayah negara sebagai harta pribadi raja. ${ }^{12}$ Namun penerapan konsep hukum privat dapat menghambat konsep hukum internasional modern, terutama ketika terjadi peralihan suatu wilayah di antara Negara-negara, apakah dapat dianggap sebagai peralihan hak milik atas tanah di antara individu-individu. Bentuk peralihan wilayah yang paling sering terjadi ketika suatu wilayah jajahan mendapatkan kemerdekaan dan karena wilayah adalah unsur utama bagi eksistensi suatu Negara, maka lahirnya Negara dan peralihan wilayah tidak dapat dipisahkan satu sama lain.

Pada praktiknya, dikenal adanya berbagai cara untuk mendapatkan suatu wilayah. Ada yang dinamakan Cession, Occupation, Prescription, Operations of nature, Adjudication, Conquest, Acquiescence, Recognition dan Estoppel. Cession adalah pengalihan wilayah dari satu Negara kepada Negara lain yang biasanya dilakukan melalui perjanjian. Jika hak dari Negara yang

12 Ibid. 
menyerahkan mengandung kelemahan atau cacat, maka hak dari Negara yang menerima penyerahan akan menjadi rusak atau cacat, sebagaimana dinyatakan dalam peribahasa Latin yang berbunyi 'nemo dat quod non habet $^{\prime 13}$, yang artinya tak seorangpun dapat memberikan sesuatu yang tidak dimilikinya. Orang yang tidak memiliki hak tidak mungkin dapat memberikan hak itu kepada orang lain sehingga hanya orang yang benar-benar memiliki hak yang dapat memberikan hak itu kepada orang lain. Misalnya dalam kasus Pulau Palmas (the Island of Palmas Case), berdasarkan Traktat Paris 1898 Spanyol menyerahkan kepulauan Philipina kepada AS. Dalam perjanjian ini Pulau Palmas dideskripsikan sebagai bagian dari Philipina. Namun ketika AS berupaya menguasai Pulau Palmas, ternyata pulau ini berada di bawah pengawasan dan pengendalian Belanda.

Dalam arbitrasi yang diadakan antara AS dan Belanda, AS mengklaim bahwa pulau itu dimiliki oleh Spanyol sebelum tahun 1898, dan bahwa AS memperolehnya dari Spanyol dengan cara yang disebut 'cession' atau penyerahan. Arbitrator Max Huber memutuskan bahwa meskipun Spanyol pada mulanya memiliki kedaulatan atas Pulau Palmas, Nederland telah melaksanakan administrasi pemerintahan di pulau itu sejak awal abad ke-18. Dengan demikian, Nederland menggantikan Spanyol sebagai penguasa atas pulau itu. Karena Spanyol tidak memiliki hak atas pulau tersebut pada tahun 1898, maka AS sudah tidak mungkin mendapatkan hak atas pulau tersebut dari Spanyol sehingga berlakulah peribahasa Latin yang berbu-

13 Michael Akehurst (1983), A Modern Introduction to International Law(Fourth Edition), London: George Allen and Unwin, p.142. nyi 'nemo dat quod non habet' yang artinya tak seorangpun dapat memberikan kepada orang lain apa yang tidak dimilikinya. Spanyol tidak dapat memberikan kepada AS pulau Palmas karena pulau ini bukan milik Spanyol, melainkan milik Nederland.

Namun demikian, apa yang disebut 'cession' yang diterjemahkan sebagai pemberian, pengalihan atau penyerahan, adalah salah satu cara untuk memperoleh hak atau kedaulatan atas suatu wilayah tertentu asal saja negara yang menyerahkan wilayah itu kepada negara lain benar-benar memilki hak yang sah atas wilayah tersebut sehingga hak negara lain tidak menjadi cacat, tetapi sah adanya.

Cara lain untuk mendapatkan hak atas suatu wilayah adalah 'occupation' yang berasal dari bahasa Latin 'occupatio' yang dikenal dalam konsep hukum Romawi yang berarti tindakan administratif dan bukan berarti tindakan pendudukan secara fisik. Occupation atau lebih tepat effective occupation sebagai tindakan administratif penguasaan atas suatu wilayah hanya bisa diterapkan pada terra nullius atau wilayah tak bertuan, atau wilayah yang dianggap tak bertuan dan dipersengketakan oleh negara-negara. Effective occupation tidak bisa diterapkan kepada wilayah yang sudah diatur dan ditentukan di dalam perjanjian, keputusan hakim, keputusan arbitrasi, atau registrasi kepemilikan dengan hukum yang jelas. ${ }^{14}$

Occupation adalah suatu cara untuk mendapatkan wilayah, tetapi wilayah yang dimaksudkan adalah wilayah yang sebelum diakuisisi merupakan wilayah yang tidak bertuan atau yang tidak ada pemiliknya (terra

14 David H. Ott, Op.Cit., p.105. 
nullius). Wilayah seperti itu mungkin saja tidak pernah dimiliki oleh Negara manapun, atau mungkin saja wilayah itu ditelantarkan (abandoned) oleh Negara terdahulu. Dewasa ini hanya sedikit wilayah yang merupakan wilayah tidak bertuan (terra nullius), tetapi tidak sedikit persengketaan wilayah yang dewasa ini terjadi berasal dari abad-abad sebelumnya, ketika wilayah sering diakuisisi atau diperoleh dengan cara melakukan okupasi atau pendudukan (occupation). Pada abad-abad sebelumnya para ahli hukum internasional yang berasal dari benua Eropa ada kalanya tidak mau mengakui masyarakat dari luar Eropa dapat membangun Negara dalam pengertian hukum internasional, dan wilayah yang dihuni oleh bangsa-bangsa bukan Eropa kadang-kadang dianggap sebagai 'terra nullius'.

Pendudukan atas suatu wilayah dapat dilakukan apabila pendudukan itu didasarkan atas pengendalian efektif (effective control). Dalam hukum internasional syarat ' $e f-$ fective control' menjadi sesuatu yang bersifat mutlak karena wilayah yang belum diduduki atau dikuasai semakin langka karena pada umumnya sudah dikuasai. Pada abad ke-16 ketika ditemukan banyak wilayah yang belum diduduki dan dikuasai, maka 'effective control' ditafsirkan secara sangat bebas.

Hanya dengan penemuan (discovery) suatu Negara dapat memperoleh hak yang bersifat sementara (inchoate title), yaitu suatu opsi bagi Negara yang bersangkutan untuk menduduki dan menguasai wilayah tersebut dalam waktu yang wajar sehingga Negara-negara lain tidak diperkenankan untuk menduduki dan menguasai wilayah tersebut. Kemudian hukum internasional mensyaratkan adanya 'effective control' untuk mendapatkan hak atas wilayah itu.

Namun dewasa ini, 'effective control' sudah berkembang menjadi sebuah konsep yang bersifat relatif karena harus disesuaikan dengan kondisi dari wilayah yang bersangkutan. Misalnya saja jauh lebih mudah membuktikan adanya 'effective occupation' atas suatu wilayah kalau wilayah itu merupakan wilayah tandus dan tidak didiami (barren and uninhabited territory) dibandingkan 'effective occupation' atas wilayah yang didiami oleh suku-suku bangsa yang masih biadab.

Di wilayah yang disebut terakhir barangkali harus ditempatkan pasukan untuk menjamin 'effective occupation', tetapi untuk wilayah tandus dan tidak didiami tidak perlu menempatkan pasukan seperti itu. 'Effective control' juga bersifat relatif dalam pengertian lain, sebagaimana ditegaskan oleh Mahkamah Internasional Permanen dalam kasus 'Eastern Greenland Case':15

Another circumstance which must be taken into account... is the extent to which sovereignty is claimed by some other power. In most of the cases involving claims to teritorial sovereignty which have come before an international tribunal, there have been two competing claims to sovereignty, and the tribunal has had to decide which of the two is the stronger...In many cases the tribunal has been satisfied with very little in the way of actual exercise of sovereign rights, provided that the other state could not make out a superior claim. This is particularly true in the case of claims to sovereignty over areas in thinly populated or unsettled countries.

(Faktor lain yang harus mendapat perhatian adalah sejauh mana kedaulatan itu dapat diklaim oleh Negara lain. Dalam

$15 \quad$ Ibid, p. 143. 
kebanyakan kasus menyangkut klaim kedaulatan teritorial yang diajukan di depan tribunal internasional, terjadi persaingan di antara dua klaim kedaulatan, dan tribunal harus memutuskan klaim mana di antara keduanya yang lebih kuat... Dalam banyak kasus tribunal setidaktidaknya mensyaratkan adanya pelaksanaan hak-hak kedaulatan secara nyata (actual exercise of sovereign rights), dengan catatan klaim yang dilakukan negara lain tidak besar, terutama kalau daerah yang diklaim adalah daerah yang ternyata kurang penduduknya atau tidak didiami.)

Dalam kasus 'Eastern Greenland', dinya-takan bahwa untuk mendapatkan wilayah dengan cara okupasi, maka suatu Negara selain harus menjalankan 'effective control', juga harus memiliki maksud dan keinginan untuk bertindak sebagai penguasa (the intention and will to act as sovereign). ${ }^{16}$ Dengan demikian, tindakan yang dilakukan dengan bebas oleh individu perseorangan dapat dikatakan tidak bernilai kecuali dapat dibuktikan bahwa dia bertindak sesuai kewenangan yang diterima dari pemerintah atau negaranya atau bahwa pemerintahnya telah menegaskan yurisdiksinya melalui individu yang bersangkutan. ${ }^{17}$

Sebagaimana dengan 'occupation', maka 'prescription' didasarkan atas 'effective control' atas suatu wilayah. Seperti dalam hal 'occupation', 'effective control' mungkin saja harus disertai dengan maksud dan kehendak untuk melakukan tindakan sebagai penguasa atas wilayah tersebut. Perbedaan antara 'prescription'dan 'occupation' adalah bahwa yang disebut pertama, yaitu 'prescription' adalah mendapatkan wilayah

16 Ian Brownlie, Op.Cit., pp.143-144.

17 Peterson, "Antarctica: the Last Great Land Rush on Earth", International Organization, Vol.34, 1980, p.377. yang dimiliki Negara lain, sedangkan 'occupation' adalah mendapatkan wilayah yang tidak dimiliki negara lain atau wilayah yang tidak bertuan (terra nullius). Negara yang melakukan pengawasan efektif (effective control) perlu membuktikan dan menetapkan haknya berdasarkan penguasaan yang lama (prescription). Pengawasan efektif harus dapat bertahan untuk jangka waktu yang lama dibandingkan dengan perlunya pengawasan efektif dalam hal 'occupation'. Hilangnya hak dari bekas penguasa mudah diduga. Dalam hukum Inggeris seorang penghuni liar (squatter) dapat memperoleh hak atas tanah setelah 12 belas tahun. Dalam hukum internasional tenggang waktunya tidak pasti, tetapi waktu yang diperlukan hampir pasti melebihi 12 tahun lamanya.

'Effective control' yang dilakukan oleh Negara yang mendapatkan suatu wilayah mensyaratkan tidak adanya protes dari Negara yang kehilangan wilayahnya atau haknya (the losing states). Akan tetapi jika protes itu terjadi secara meluas dan berulangulang, maka hal ini dapat mencegah atau menyebabkan tidak adanya hak berdasarkan prescription. Mengapa pihak arbitrator menekankan tidak adanya protes dari Spanyol terhadap tindakan-tindakan Belanda atas pulau tersebut, hal ini dijelaskan dalam kasus Pulau Palmas.

Meskipun secara teoritis dapat dibedakan antara pendudukan (occupation) dan penguasaan lama (prescription), perbedaan ini biasanya menjadi kabur dalam kehidupan nyata sebab salah satu hal yang justru sering dipersengketakan adalah apakah wilayah itu adalah tanah tidak bertuan (terra nullius) atau apakah wilayah itu berada di bawah ke- 
daulatan dari Negara pertama sebelum $\mathrm{Ne}-$ gara kedua tiba di daerah yang bersangkutan. Misalnya putusan dalam kasus Pulau Palmas tidak menjelaskan apakah pulau ini berada di bawah kedaulatan Spanyol sebelum Belanda mulai menjalankan pengawasan atas pulau itu.

Banyak kasus yang diklasifikasi dalam buku-buku teks sebagai kasus 'occupation' dapat dipersamakan dengan kasus 'prescription', demikian pula sebaliknya. Apabila menghadapi persaingan klaim (competing claims), maka tribunal-tribunal internasional sering menjatuhkan putusan yang menguntungkan negara yang dapat membuktikan 'effective control' yang dilakukannya atas wilayah yang dipersengketakan sungguhsungguh kuat, tanpa mendasarkan putusannya mengenai suatu cara akuisisi yang sifatnya khusus. Misalnya dalam kasus 'the Eastern Greenland', Mahkamah Internasional Permanen memberi putusan yang menguntungkan Denmark karena Denmark menjalankan pengawasan yang lebih besar dibandingkan pengawasan Norwegia terhadap Eastern Greenland, tetapi Mahkamah tidak menyebut secara terperinci mengenai bagaimana cara Denmark mendapatkan kedaulatan itu. ${ }^{18}$

Perolehan kemerdekaan sebuah daerah jajahan melalui proses pembangunan

18 Daerah jajahan yang mendapatkan kemerdekaan melalui proses pembangunan yang dijalankan secara tahap demi tahap berdasarkan konstitusi dapat dianggap sebagai 'quasi -prescription'. Kemerdekaan, kedaulatan dan hak territorial yang diperoleh Australia, Kanada dan Selandia Baru dapat disebut 'quasi-prescription' karena ketiga negara ini mendapatkan hak atau kedaulatan teritorialnya melalui pembangunan yang dilakukan secara bertahap sebagaimana diamanatkan dalam konstitusi masing-masing negara. bertahap secara konstitusional sebagaimana terjadi dalam kasus Australia, Kanada dan Selandia Baru dapat dianggap semacam 'quasi-prescription'. Suatu Negara dapat memperoleh wilayah melalui apa yang dinamakan aktivitas alam (operations of nature), misalnya ketika sungai tertimbun lumpur, atau ketika pulau vulkanik muncul di perairan pedalaman atau laut teritorial dari suatu Negara. Negara tersebut wilayahnya mengalami perluasan wilayah sebagai akibat proses alam sehingga wilayahnya bertambah luas.

Ada pula cara akuisisi yang dinamakan 'adjudication' yang diartikan sebagai cara perolehan wilayah, tetapi status wilayah ini masih menimbulkan keraguan sehingga perlu diselesaikan. Secara teoritis, pengadilan lazimnya bertugas untuk mendeklarasikan atau menyatakan hak-hak yang telah dimiliki para pihak, bukan untuk menciptakan hak-hak baru. Menurut teori 'adjudication' ini, negara tidak diberikan suatu wilayah yang sudah tidak dimilikinya lagi.

Di pihak lain, ada kalanya terjadi Negara-negara membentuk suatu komisi perbatasan untuk menandai garis batas yang telah disepakati, tetapi selama ini komisi seperti ini diberi wewenang untuk menyimpang dan mengubah garis perbatasan yang telah disepakati (misalnya untuk mencegah terbaginya tanah pertanian menjadi dua); namun kewenangan komisi perbatasan tersebut bersumber dari perjanjian yang membentuknya, sehingga apabila terjadi peralihan wilayah. Maka hal ini dapat dianggap semacam penyerahan yang sifatnya tidak langsung (indirect cession). ${ }^{19}$

19 Michael Akehurst, Op.Cit., p.146. 
Cara lain dalam mengakuisisi suatu wilayah adalah cara yang disebut çonquest'. Negara yang kalah perang biasanya menyerahkan wilayahnya atau sebagian wilayahnya kepada pihak yang menang dan hal seperti ini lazimnya dilakukan dengan perjanjian, tetapi berdasarkan hukum tradisional tindakan penaklukan itu sendiri (conquest), walaupun tanpa perjanjian, juga dapat memberikan hak (title) kepada pihak pemenang. Akuisisi wilayah dengan cara penaklukan itu tidak sah kecuali perang telah berakhir. Jika Negara yang kalah membuat perjanjian perdamaian dan menyerahkan wilayah tersebut kepada Negara pemenang, dengan kata lain perjanjian itu mengakui hak dari Negara pemenang, maka jelaslah bahwa perang itu sudah berakhir.

Dalam hal tidak ada perjanjian perdamaian, maka perlu membuktikan kalau perang itu sudah berakhir dengan cara yang berlainan, dengan menyampaikan buktibukti nyata bahwa semua resistensi atau penentangan oleh Negara musuh maupun sekutu-sekutunya telah terhenti. Dengan demikian, aneksasi yang dilakukan oleh Jerman terhadap Polandia selama Perang Dunia II itu tidaklah sah karena para sekutu Polandia terus berjuang melawan Jerman. Di samping itu, Negara penakluk hanya mendapatkan wilayah atau hak atas wilayah itu jika Negara itu memang berniat dan bermaksud untuk menganeksasi dan menguasai wilayah tersebut. Pada tahun 1945 negara-negara sekutu menegaskan tidak bermaksud untuk menganeksasi Jerman, meskipun mereka telah menduduki seluruh wilayah Jerman dan mengalahkan semua sekutunya.
Di abad XIX, tidak terelakkan seharusnya hukum internasional memperkenankan negara-negara untuk mendapatkan wilayah melalui tindakan penaklukan (by conquest) karena pada waktu itu hukum kebiasaan internasional tidak membatasi hak Negaranegara untuk berperang. Selama abad kedua puluh timbul gerakan yang berkulminasi dan mencapai puncaknya pada Piagam PBB, untuk membatasi hak Negara-negara untuk melakukan peperangan. Sebagai asas umum, penggunaan kekerasan adalah suatu tindakan yang tidak sah, tetapi ada beberapa pengecualian seperti tindakan pembelaan diri. Bagaimana pengaruhnya ketika timbul perubahan yang bersifat revolusioner di dalam hukum terhadap kemungkinan mengakuisisi wilayah dengan melakukan penaklukan?

Sebagaimana diketahui suatu perjanjian yang dibuat oleh Negara aggressor dewasa ini batal dengan sendirinya. Karena Negara aggressor tidak bisa memperoleh wilayah dengan cara menaklukkan Negara lain dan memaksanya untuk menadatangani perjanjian 'cession', maka a fortiori Negara aggressor tidak mungkin mendapatkan wilayah dengan jalan penaklukan itu sendiri (conquest). Akan tetapi selama komunitas internasional tidak dapat mencegah para aggressor menikmati hasil dari kejahatan yang dilakukannya, maka gagasan aggressor tidak dapat memperoleh hak wilayah secara baik (a good title to territory) gagasan ini besar kemungkinan mengakibatkan ketidaksesuaian antara hukum dan faktafakta.

Secara teoritis, fakta-fakta seharusnya diverifikasi dengan peraturan hokum. Namun apabila negara tidak siap atau tidak 
bersedia merubah fakta-fakta itu, maka alternatif satu-satunya adalah memverifikasi peraturan hukum itu dengan fakta-fakta, dengan cara memberikan pengakuan. Hak aggressor samasekali tidak sah karena hak seperti ini didasarkan atas agresi, tetapi kelemahannya dapat diatasi apabila Negara-negara lain mengakuinya secara de jure. ${ }^{20}$ Dalam keadaan luar biasa pengakuan membawa akibat yang bersifat konstitutif. Bagaimana dengan pihak-pihak berperang yang tidak bersalah? Masih dapatkah mereka memperoleh wilayah dengan cara penaklukan?

The Declaration on Principles of International Law concerning Friendly Relations and Cooperation among States in Accordance with the Charter of the United Nations, yang telah disahkan oleh Majelis Umum tahun 1970, menganjurkan agar wilayah suatu Negara tidak boleh menjadi obyek pendudukan militer akibat penggunaan kekerasan dengan cara yang bertentangan dengan ketentuan-ketentuan Piagam. Wilayah suatu Negara tidak boleh menjadi obyek akuisisi oleh Negara lain dengan cara mengancam atau menggunakan kekerasan.

Atas dasar ini, Deklarasi membedakan secara signifikan antara pendudukan militer (military occupation) dan perolehan wilayah (acquisition of territory). Pendudukan militer menjadi tidak sah hanya jika hal seperti ini terjadi akibat penggunaan kekerasan yang bertentangan dengan Piagam; setiap ancaman atau penggunaan kekerasan, apakah bertentangan dengan Piagam atau tidak bertentangan, dapat menyebabkan akuisisi atau perolehan wilayah tersebut menjadi tidak sah.

$20 \quad$ Ibid, p. 147.
Setelah permusuhan Arab - Israel pada bulan Juni 1967, Dewan Keamanan dan Majelis Umum PBB tidak mengutuk salah satu pihak atas tindakan agresi yang dilakukannya. Rancangan resolusi yang mengutuk Israel digagalkan. Akan tetapi Majelis Umum dan Dewan Keamanan berkali-kali menyatakan dengan jumlah suara sangat besar bahwa Israel tidak berhak mencaplok setiap wilayah yang diserbu oleh Israel - yang selanjutnya mendukung pandangan bahwa dewasa ini larangan mengakuisisi wilayah dengan cara kekerasan berlaku bagi semua Negara, dan tidak hanya berlaku bagi Negara yang melakukan agresi. Sebagaimana hakhak (titles) yang didasarkan atas penaklukan oleh aggressor dapat disahkan (validated) melalui adanya pengakuan de jure oleh negara-negara lain, demikian pula hak-hak yang didasarkan atas penaklukan oleh Negara bukan aggressor juga dapat divalidasi melalui pengakuan seperti itu. ${ }^{21}$

Dewasa ini, penaklukan untuk mengakuisisi wilayah tidak diperbolehkan dalam perang yang bersifat internasional (international wars). Akan tetapi ketika timbul perang saudara (civil war), di mana sebagian penduduk dalam suatu Negara berhasil mendirikan sebuah Negara baru sehingga sesungguhnya terjadi akuisisi atas sebagian wilayah melalui penaklukan dalam perang saudara, maka penaklukan seperti ini tidak dilarang.

Selanjutnya, dikenal pula apa yang dinamakan 'Acquiescence', 'Recognition' and 'Estoppel'. Ketiga-tiganya memainkan peran sangat penting dalam memperoleh

21 Ibid. David H.Ott, Public International Law in the Modern World, London: Pitman Publishing, 1987, p. 106. 
suatu wilayah, meskipun semuanya ini bukan merupakan cara-cara akuisisi. Apabila suatu Negara yang bersaing (rival claimants) dapat menunjukkan bahwa dia sudah menjalankan semacam penguasaan atas wilayah yang dipersengketakan, maka tribunal internasional mungkin sekali dapat memberi putusan yang menguntungkan Negara yang dapat membuktikan bahwa haknya telah diakui oleh Negara-negara lain. Pengakuan seperti ini dapat berbentuk pernyataan tegas, ataupun pengakuan itu dapat disimpulkan dari adanya persetujuan diam-diam (acquiescence), yaitu tidak adanya protes oleh pihak lawan terhadap pelaksanaan penguasaan atas wilayah yang bersangkutan.

Namun dalam setiap kasus pengakuan (recognition) atau pengakuan diam-diam (acquiescence), pengaruhnya kecil atau tidak mempunyai pengaruh kecuali pengakuan itu disertai dengan tindakan penguasaan terhadap wilayah itu oleh Negara lain; tidak adanya protes terhadap pernyataan yang hanya bersifat verbal mengenai hak yang tidak ditunjang dengan semacam penguasaan tidak dapat disebut sebagai persetujuan diam-diam (acquiescence).

Kadang-kadang dikatakan bahwa pengakuan (recognition) atau persetujuan diamdiam (acquiescence) menghasilkan suatu estoppel. Estoppel adalah aturan hukum Inggeris yang bersifat teknis mengenai pembuktian (evidence). Apabila salah satu pihak membuat pernyataan tentang fakta dan pihak lain melakukan suatu tindakan berdasarkan pernyataan tersebut, maka pengadilan tidak akan memperkenankan pihak pertama membantah atau menyangkal kebenaran dari pernyataannya jika pihak yang telah bertindak berdasarkan pernyataan itu akan menderita kerugian dalam hal pernyataan itu terbukti salah. Dikaitkan dengan sengketa teritorial yang sifatnya internasional, kaidah seperti itu menunjukkan bahwa suatu Negara yang telah mengakui hak Negara lain atas wilayah tertentu harus berhenti mengingkari hak Negara lain jika Negara lain telah melakukan suatu tindakan atas dasar pengakuan, misalnya dengan membangun jalanan di wilayah yang bersangkutan, karena Negara yang membangun jalanan itu anggarannya terhambur begitu saja jika haknya ternyata tidak diakui.

Sikap hukum internasional terhadap estoppel tidak selalu konsisten. Kadang-kadang hukum internasional menghendaki adanya syarat reliance and detriment; di waktu lain hukum internasional tidak mensyaratkan syarat seperti itu. Lagi pula estoppel dalam hukum internasional kadang-kadang berakibat satu pihak tidak dimungkinkan untuk menentang pernyataan sebelumnya, seperti dalam hukum Inggeris. Dalam kasus-kasus lain estoppel itu hanya merupakan fakta atau bukti, yaitu satu pihak sulit untuk menentang atau membantah pernyataan sebelumnya.

Seperti diketahui acquiescence dan recognition memainkan peranan krusial dalam kasus-kasus prescription. Akan tetapi, acquiescence dan recognition pun relevan dengan cara-cara lain dalam melakukan akuisisi. Misalnya,dalam kasus 'the Eastern Greenland', Norwegia mengklaim mendapatkan Eastern Greenland melalui occupation - suatu klaim yang mensyaratkan bahwa Eastern Greenland adalah tanah tidak bertuan (terra nullius) sebelum klaim itu dilakukan oleh Norwegia, negeri ini ke- 
hilangan klaim tersebut karena 1) Denmark lebih kuat atau efektif penguasaannya atas Eastern Greenland ketimbang apa yang dilakukan oleh pihak Norwegia, dan karena 2) Norwegia dengan tindakan-tindakan yang dilakukannya telah mengakui hak Denmark terhadap seluruh wilayah Greenland. ${ }^{22}$ Persetujuan diam-diam dan pengakuan juga menjadi penting dalam menafsirkan perjanjian cession.

Negara-negara tidak lagi diperkenankan mengakuisisi wilayah dengan cara melakukan penaklukan (conquest), tetapi tidak sahnya akuisisi seperti itu dapat dihilangkan dan diatasi melalui pengakuan. Akan tetapi dalam konteks ini pengakuan itu harus mengikuti aturan-aturan yang sudah ditentukan. Pertama, pengakuan tersebut harus dilakukan dalam bentuk pernyataan tegas (express statement) dan tidak dapat dilakukan secara diam-diam. ${ }^{23}$ Kedua, pengakuan itu tidak dapat dilakukan untuk mengesahkan akuisisi wilayah lewat penaklukan kecuali pengakuan tersebut adalah pengakuan de jure. Ketiga, pengakuan oleh korban penaklukan harus disertai dengan pengakuan negara ketiga, sebagian karena akuisisi wilayah secara kekerasan adalah merupakan masalah yang menimbulkan keprihatinan bagi seluruh masyarakat internasional, dan sebagian lagi karena pengakuan Negara ketiga dibutuhkan untuk membuktikan bahwa negara korban memberikan pengakuan secara bebas dan tanpa paksaan. ${ }^{24}$

Aturan-aturan akuisisi wilayah telah mengalami perubahan selama berabad-abad.

22 Ibid, p.149. (1933, PCIJ, series A/B, no. 53, at p. 68).

23 Ibid, p.149. H. Lauterpacht, Recognition in International Law, 1947, pp.395 - 396.

24 Michael Akehurst, Op.Cit, p.150.
Hal ini menimbulkan persoalan hukum antarwaktu (intertemporal law); hukum dari abad mana yang harus diterapkan dalam menentukan validitas atau keabsahan hak atas wilayah? Pandangan yang umumnya diterima adalah bahwa akuisisi wilayah validitasnya bergantung pada hukum yang berlaku pada saat terjadinya akuisisi itu. Solusi ini sesungguhnya tidak lain hanya sebuah contoh terkait adanya asas yang berlaku umum bahwa undang-undang tidak boleh berlaku surut. $^{25}$

Ironisnya, selama ini pandangan seperti itu sudah dikesampingkan dalam kasus Pulau Palmas, dimana arbitrator Max Huber mengatakan bahwa harus dibedakan antara terciptanya hak (the creation of rights) dan adanya hak (the existence of rights). Terciptanya hak sesuai hukum yang berlaku pada waktu timbulnya hak itu merupakan prinsip yang menghendaki agar keberadaan suatu hak (the existence of a right) harus sesuai dengan persyaratan hukum yang sedang berlaku. Karena persyaratan hukum dalam mengakuisisi wilayah semakin keras, maka suatu Negara harus semakin lama semakin mampu mempertahankan haknya; Negara tersebut harus terus menerus berada di tempat yang sama. ${ }^{26}$

\section{Berbagai Kasus terkait Pengendalian Efektif (Effective Occupation) ${ }^{27}$}

Kemenangan Malaysia atas Indonesia dalam kasus Pulau Sipadan dan Pulau Ligitan di depan Mahkamah Internasional didasarkan atas prinsip pengendalian efektif (effective

${ }_{25}$ See 'the Western Sahara case', ICJ Reports, 1975, pp. 12,37 - 40

26 Michael Akehurst, op.cit., p.150.

27 ICJ Report 17 December 2002, paras 126-129; Jurisdictionary, Vol.1 No.2 April 2005, Hlm. xx. 
occupation) yang merupakan asas hukum internasional umum. Masing-masing negara mengajukan prinsip seperti itu dalam berbagai bentuk kegiatan terkait dengan kedua pulau yang dipersengketakan dalam rangka membuktikan hak kepemilikannya. Namun berbagai kegiatan atau tindakan yang dilakukan Malaysia ataupun pendahulunya terkait kedua pulau tersebut membuktikan terpenuhinya prinsip pengendalian efektif sehingga kedua pulau tersebut dinyatakan sebagai milik Malaysia.

Demikian pentingnya prinsip pengendalian efektif sebagai asas hukum internasional yang dapat menciptakan hak atau kedaulatan atas suatu wilayah, maka berikut ini akan dibahas prinsip tersebut dengan mengemukakan pelbagai kasus yang telah diputuskan oleh arbitrasi ataupun peradilan internasional. Kasus-kasus itu antara lain adalah kasus persengketaan Pulau Palmas (Palmas Island Case) yang melibatkan Pemerintah Hindia Belanda dan Amerika Serikat, kasus Clipperton Island antara Pemerintah Perancis dan Meksiko dan kasus Eastern Greenland antara Denmark dan Norwegia serta kasus-kasus teritorial lainnya yang telah diputuskan oleh pengadilan internasional. ${ }^{28}$

\section{Sengketa Pulau Palmas: Amerika Serikat} v. Hindia Belanda

Dalam kasus Pulau Palmas, Arbitrator yang bernama Max Huber mengatakan bahwa jika kedaulatan teritorial dijalankan secara terus menerus dan damai atau tidak ditentang oleh negara lain, maka hal seperti ini sama dengan hak atau 'title', yaitu terciptanya hak. Manifestasi kedaulatan teritorial sesungguhnya

${ }_{28}$ Michael Akehurst, op.cit., p.143. mempunyai berbagai bentuk sesuai dengan situasi dan kondisi setempat. Meskipun pada prinsipnya pelaksanaan kedaulatan harus terus menerus, dalam kenyataan kedaulatan itu tidak mungkin dilaksanakan setiap saat dan di tempat dalam suatu wilayah. Kedaulatan teritorial itu mensyaratkan pelaksanaan fungsi-fungsi negara secara terus menerus dan damai. ${ }^{29}$

Hak Amerika Serikat yang didasarkan atas penemuan (discovery) Pulau Palmas oleh Spanyol, perjanjian Paris 1898 yang berisi penyerahan semua hak yang dimiliki Spanyol kepada Amerika Serikat dan dekatnya pulau tersebut dengan kepulauan Philipina, semuanya ini tidak dapat membuktikan kalau Spanyol menjalankan kedaulatannya atas Pulau Palmas.

Selanjutnya, Max Huber menguji argumentasi Pemerintah Hindia Belanda soal pelaksanaan kedaulatan negara atas pulau tersebut yang dijalankan secara terus menerus dan damai. Menurutnya penduduk pulau tersebut sudah menjalin hubungan dan komunikasi dengan perusahaan Inggeris yang berada di India, yaitu the East India Company. Sejak tahun 1677 dibuat semacam kontrak antara pïhak Hindia Belanda dengan pihak raja-raja yang ada di Pulau Palmas dan akibatnya pulau yang dahulu terpecil atau terisolasi lalu menjadi wilayah yang bersifat terbuka sehingga terjalin hubungan antara negara kolonial dan daerah jajahan.

Semuanya ini menunjukkan bahwa antara tahun 1700 sampai tahun 1906 pelaksanaan kedaulatan Hindia Belanda di pulau tersebut telah berjalan secara damai atau ti-

29 Malcolm N. Shaw (1986), International Law, Cambridge, Grotius Publications Limited, Hlm. $240-241$. 
dak mendapat perlawanan dari Negara lain sehingga hal ini membuktikan adanya kedaulatan Negara tersebut terhadap pulau yang bersangkutan ${ }^{30}$.

Sengketa Pulau Clipperton: Meksiko v. Perancis

Kasus Clipperton Island yang melibatkan dua Negara, yakni Perancis dan Meksiko juga ditangani dan diselesaikan oleh arbitrasi internasional berdasarkan atas persetujuan kedua Negara tersebut. Meksiko mengklaim hak atas pulau yang berdekatan dengan kepulauan Hawai di Samudera Pasifik dengan alasan bahwa pulau itu diduga ditemukan pertama kali oleh Spanyol. Akan tetapi arbitrator menyatakan bahwa walaupun pihak Meksiko memiliki hak historis terkait statusnya sebagai Negara pengganti atas Spanyol, namun hak seperti ini tidak ditunjang dengan pelaksanaan kedaulatan atas Pulau Clipperton.

Perancis menyatakan pulau tersebut adalah tanah yang tidak bertuan (terra nullius) ketika seorang perwira Angkatan Laut Perancis singgah dan mendarat di pulau Clipperton dan kemudian melakukan proklamasi kedaulatan Perancis atas pulau itu pada tahun 1858. Masalahnya menurut pihak arbitrasi adalah apakah Perancis sudah mulai melakukan apa yang disebut 'effective occupation' pada waktu itu. Jika Perancis tidak melakukan pengendalian efektif, maka menurut arbitrasi Meksiko tentu saja mempunyai hak untuk beranggapan bahwa pulau tersebut dapat didudukinya pada tahun $1897 .{ }^{31}$

$30 \quad$ Ibid, hlm. 241.

31 Ian Brownlie, Op.Cit., pp.152 - 153.
Arbitrator menyatakan adanya 'effective occupation' mensyaratkan adanya tindakan penguasaan aktual (an actual taking of possession), yaitu suatu tindakan atau serangkaian tindakan yang bertujuan untuk menguasai suatu wilayah. Pada umumnya 'an actual taking of possession' atau tindakan penguasaan aktual hanya terjadi apabila Negara yang bersangkutan mendirikan di dalam wilayah tersebut sebuah organisasi yang mampu menciptakan peraturan hukum dan peraturan hukum ini dipatuhi dan dihormati. Namun tindakan atau langkah seperti ini hanyalah salah satu cara untuk melakukan tindakan penguasaan aktual, sehingga hal ini tidak sama dengan tindakan penguasaan aktual (an actual taking of possession).

Menurut arbitrator, terdapat kasuskasus yang memperlihatkan bahwa tindakan menciptakan peraturan tidak selalu harus digunakan sebagai cara untuk melakukan penguasaan. Jika ternyata suatu wilayah sama sekali tidak berpenduduk, tetapi kemudian diduduki atau dikuasai secara aktual oleh suatu negara dengan melakukan semacam proklamasi kedaulatan atas wilayah itu, maka sejak proklamasi ini tindakan penguasaan seperti ini (an actual taking of possession) harus dianggap tuntas dan 'occupation' yang dilakukannya telah sempurna adanya.

Dengan demikian, menurut arbitrator, Perancis memperoleh pulau Clipperton ketika Negara ini melalui perwira Angkatan Laut membuat proklamasi kedaulatan terhadap pulau tersebut pada 17 November 1858 dan okupasi atau aneksasi tersebut meskipun hanya bersifat simbolis secara jelas telah menimbulkan akibat hukum. 
Sengketa Pulau Sipadan dan Pulau Ligitan: Indonesia v. Malaysia

Dalam kasus Pulau Sipadan dan Ligitan, pihak Indonesia sudah berupaya membuktikan haknya menurut hukum (legal title) atas kedua pulau tersebut, dalam hal ini didasarkan atas Konvensi London 1891. Untuk memperkuat hak hukum ini, Nederland sebenarnya telah menjalankan pengendalian efektif atas kedua pulau tersebut melalui serangkaian fungsi pemerintahan di perairan sekitar kedua pulau tersebut, antara lain beroperasinya kapal Angkatan Laut Kerajaan Belanda yang disebut HMS Lynx yang melakukan kegiatan patroli pengawasan dan penanggulangan terhadap berbagai macam kejahatan, khususnya aksi kejahatan perompakan (piracy) yang terjadi di kawasan, termasuk perairan sekitar Sipadan dan Ligitan.

Pengendalian efektifvitas wilayah pulau Sipadan juga dapat diketahui dari adanya tulisan-tulisan yang tertera pada sebuah tugu yang didirikan di pulau itu oleh otoritas Hindia Belanda. Kegiatan surveilans yang dilaksanakan oleh kapal-kapal patroli Hindia Belanda dan kemudian dilanjutkan oleh Pemerintah Indonesia, dan akhirnya kegiatan nelayan-nelayan tradisional Indonesia yang melakukan penangkapan ikan di perairan sekitar pulau-pulau perbatasan, termasuk di dalamnya Pulau Sipadan dan Pulau Ligitan, semuanya ini membuktikan terciptanya hak (title) Indonesia atas kedua pulau tersebut.

Semua kegiatan tersebut menunjukkan berjalannya fungsi-fungsi administrasi pemerintahan sejak zaman kolonial yang merupakan pencerminan dari asas 'effective occupation'. Namun demikian, bagi ICJ apa yang dikemukakan oleh pihak Indonesia, termasuk tindakan-tindakan yang dilakukan oleh Belanda tidak berkarakter legislasi sehingga semuanya bukan merupakan 'effective occupation'.

Penetapan peta oleh Pemerintah Hindia Belanda yang melampirkannya pada undang-undang pengesahan Konvensi London 1891 serta 'explanatory memorandum' 1915 tersebut adalah bagian dari terselenggaranya fungsi-fungsi administrasi pemerintahan. Hal ini membuktikan terwujudnya pengendalian efektif terhadap perairan di sekitar kedua pulau yang dipersengketakan. Peta yang dilampirkan pada naskah perjanjian yang sudah diratifikasi Pemerintah Kerajaan Belanda dan ratifikasinya di Den Haag, menunjukkan adanya pengakuan Inggris terhadap makna dan substansi dari peta tersebut yang menggambarkan garis batas yang paralel dengan $4^{\circ} 10^{\prime}$ Lintang Utara sebagai garis alokasi dan pembagian kedaulatan antara kedua negara di kawasan tersebut. Hal ini disebabkan karena Konvensi London 1891 dengan peta terlampir bertujuan untuk meningkatkan hubungan persahabatan di antara negara-negara, dan pada waktu bersamaan untuk memelihara perdamaian dan keamanan internasional, termasuk di kawasan Asia Tenggara.

Peta dalam konteks Konvensi 1891 menjadi petunjuk atau bukti mengenai maksud kedua Negara dalam menetapkan garis yang ditarik dari pantai Timur Borneo dan pantai Barat Pulau Sebatik melintasi pulau ini dan berlanjut menuju ke arah Timur, sepanjang garis yang dimaksud itu sejajar dengan $4^{\circ} 10^{\prime}$ Lintang Utara ${ }^{32}$.

32 ICJ Report 2002. (paras. 81-91); Jurisdictionary, Vol.1 No.2 April 2005, Hlm. xv. 
Garis paralel seperti tercantum dalam peta tersebut mempunyai fungsi sebagai garis pembagian kedaulatan antara Inggris dan Belanda sehingga dapat memberi kontribusi bagi masyarakat internasional dalam rangka mencegah timbulnya konflik teritorial antarnegara dan pada waktu yang sama dapat menciptakan perdamaian dan keamanan internasional di kawasan tersebut.

Pihak Inggris dan Belanda delegasinya sudah mengenal situasi perbatasan pada tahun 1891 ketika kedua negara kolonial mengadakan perundingan untuk membuat perjanjian soal pembagian wilayah atas dasar garis yang ditarik dari pantai Timur Borneo atau pantai Barat Pulau Sebatik melintasi Pulau Sebatik dan berlanjut terus sepanjang garis tersebut sejajar dengan $4^{\circ} 10^{\prime}$ Lintang Utara. Semua wilayah yang terletak di sebelah utara dari garis parallel $4^{\circ} 10^{\prime}$ lintang utara adalah milik Inggris, sedang wilayahwilayah yang terletak di sebelah selatan dari garis seperti itu, termasuk pulau-pulau Sipadan dan Ligitan (di samping pulau-pulau Sebatik, Tarakan dan Nunukan) adalah milik Belanda.

\section{Pendekatan Non-Yuridis di Balik Akuisisi Sipadan-Ligitan}

Penguasaan efektif (effective occupation) sebagai cara akuisisi teritorial diterapkan oleh mahkamah, sehingga Malaysia memperoleh kedaulatan atas kedua pulau yang dipersengketakan sejak tahun 1969 ini. Akan tetapi penerapan cara seperti ini yang kendati sudah diakui sebagai hukum kebiasaan internasional, diduga beraroma kepentingan pihak ketiga atas sengketa tersebut. Kuat dugaan hal ini sulit dihindari mengingat keberadaan mahkamah di wilayah negara tertentu berkontribusi dalam pemanfaatannya oleh pihak ketiga sehingga sulit kiranya menghindari timbulnya semacam pemikiran bahwa keputusan mahkamah internasional bukan keputusan yang 'purely yuridical'.

Dugaan adanya semacam 'external interest' yang turut mengintip dan mewarnai keputusan ICJ hampir tidak mungkin terelakkan, terbukti dari hadirnya berbagai pertimbangan artifisial yang penuh alibi dan silat kata. Bukti penolakan terhadap Philipina yang ingin berpartisipasi dalam proses persidangan memperkuat dugaan tersebut, padahal keinginan negeri ini sangat wajar sebab hubungan antara Philipina dan Malaysia belum harmonis terkait masalah Sabah. Berbagai pertimbangannya dapat dikatakan penuh dengan permainan logika, tetapi sesungguhnya bersifat artifisial, sehingga menjauh dari kebenaran dan keadilan substansial yang seharusnya menjiwai setiap putusan pengadilan, tidak terkecuali pengadilan internasional.

Pertimbangan-pertimbangan artifisial yang berlabel 'effective occupation' berujung pada putusan kemenangan Malaysia untuk mengakuisisi kedua pulau, tetapi pada saat bersamaan pertimbangan-pertimbangan yang melandasi putusan seperti itu tidak dapat menyingkirkan pemikiran yang mengaitkannya dengan perlindungan kepentingan Royal Dutch, khususnya dalam bidang ekonomi dan investasi di negeri tetangga.

Pembangunan infrastruktur di kedua pulau tersebut sebelum dan setelah kasus Sipadan - Ligitan ternyata melibatkan korporasi negeri kincir angin yang relatif lama menanamkan investasinya di wilayah Ma- 
laysia, termasuk di kedua pulau yang dewasa ini telah menjadi daerah wisata termahal di seluruh dunia. Adanya perizinan atau konsesi yang diberikan Malaysia kepada perusahaan Shell asal Nederland untuk melakukan eksplorasi migas di wilayah Ambalat lepas pantai pulau Sabah tidak lama setelah keluarnya putusan ICJ pada 2002 merupakan fakta yang tidak mungkin dapat diingkari. Bukankah penerbitan dan pemberian konsesi kepada korporasi Shell seperti itu bertujuan untuk melindungi atau menjamin kepentingan Nederland dan pihak ketiga lainnya sebab ternyata berbagai referensi dan media mengungkapkan bahwa pemilik saham mayoritas dari korporasi itu tidak lain dari Pemerintah Kerajaan Belanda sendiri (Royal Dutch). ${ }^{33}$

Melalui fakta-fakta seperti itu, dapat dipahami kalau tidak jarang bermunculan adanya pemikiran bahwa putusan ICJ terkait kasus Sipadan-Ligitan itu bukan tidak mungkin diwarnai pengaruh eksternal sehingga 'effective occupation' yang digunakan sebagai dasar pengambilan keputusan hanya berfungsi sebagai label dan kemasan yuridis semata-mata. Keadaan seperti ini bukan merupakan sesuatu yang luar biasa mengingat dalam banyak kasus yang dibawa ke depan pengadilan internasional dan nasional unsur-unsur eksternal ada kalanya tidak dapat dielakkan dalam pengambilan keputusan menyangkut kasus atau perkara tertentu.

Dalam perkara Organisasi Serikat Buruh AS melawan Organisasi Negara-negara OPEC (Organization of Petroleum Export-

33 Victor Prescott and Clive Schofield (2005), The Maritime Political Boundaries of the World (Second Edition), Leiden/ Boston: Martinus Nijhoff Publishers, pp. $451-452$. ing Countries) pengadilan distrik dari negara bagian New York mengenyampingkan gugatan gantirugi melawan Organisasi OPEC dengan alasan tindakan negara-negara OPEC yang menaikkan harga minyak (price fixing) dikualifikasi sebagai tindakan negara dalam kapasitasnya sebagai subyek hukum public (iure imperii). Para buruh yang tergabung dalam organisasi tersebut mengajukan gugatan terhadap negara-negara OPEC karena 'price fixing' atau penetapan harga minyak yang mengakibatkan kenaikan harga minyak dari 15 US dollar per barrel menjadi 36 US dollar per barrel.

Kenaikan harga minyak yang ternyata menyebabkan biaya kebutuhan hidup sehari-hari membawa penderitaan dan kesengsaraan bagi penduduk, khususnya bagi kaum buruh AS sehingga menyebabkan kerugian materil dan immaterial terhadap kaum buruh yang tidak mampu menghadapi kenyataan hidup sehari-hari. Bagi mereka 'price fixing' dengan akibat meroketnya harga minyak dunia dikategorikan sebagai tindakan negaranegara OPEC (act of state) dalam kapasitas sebagai subyek hukum privat yang diistilahkan dengan iure gestionis.

Dengan tindakan yang dikualifikasi sebagai iure gestionis, mereka tidak dikecualikan dan tidak dibebaskan dari pelaksanaan kekuasaan hukum negara setempat. Namun pihak negara-negara OPEC yang diwakili oleh pihak Kejaksaan Agung AS serta para lawyer menyatakan bahwa 'price fixing' itu harus dilihat sebagai tindakan negara-negara pengekspor minyak yang dimaksudkan untuk melakukan penataan terhadap sumbersumber kekayaan alam yang terkandung di dalam perut bumi wilayah negara-negara 
OPEC, termasuk Indonesia yang pada tahun 1970-an masih kuat kedudukannya sebagai anggota OPEC sehingga berkepentingan dalam kasus gantirugi antara Serikat buruh dan OPEC. ${ }^{34}$

Keputusan pengadilan distrik yang memenangkan negara-negara OPEC, kemudian diperkuat pada tingkat banding (Court of Appeal) dan akhirnya dikukuhkan pada tingkat terakhir (Supreme Court) tidak dapat dilepaskan dari pemikiran mengenai kemungkinan adanya faktor eksternal yang memberikan kontribusi terhadap keluarnya keputusan pengadilan yang memenangkan negara-negara OPEC dalam sengketanya dengan serikat buruh AS.

Sulit terelakkan untuk tidak mengatakan tidak mungkin terhindarkan adanya dugaan masuknya kepen-tingan eksternal yang mempengaruhi keputusan badan peradilan di negeri Paman Sam. Ketergantungan AS terhadap pasokan migas yang berasal dari berbagai negara baik yang menjadi anggota OPEC, termasuk Indonesia pada masa itu ataupun di luar OPEC merupakan fakta yang menunjukkan besarnya kepentingan AS di bidang ekonomi dan investasi dan bisnis karena kepentingannya selama ini dapat diakomodasi terutama melalui berbagai perjanjian kerjasama dengan negara-negara OPEC dalam bidang perekonomian, perdagangan, bisnis dan investasi yang saling menguntungkan.

Faktor ekonomi dan juga politik seperti ini yang perlu dicermati terkait dengan lahirnya keputusan pengadilan di AS yang

34 Soedargo Gautama (1985), Soal-soal Aktual Hukum Perdata Internasional, Bandung: Binacipta, hlm. $19-20$. tidak dapat menerima tuntutan ganti-rugi organisasi serikat buruh. Bahwa putusan badan peradilannya tidak semata-mata didasarkan atas argumentasi hukum menyangkut 'legal standing' (iure gestionis dan iure imperii) dari negara-negara OPEC di depan pengadilan, tetapi juga di dalam argumentasi dan pertimbangannya tersirat kepentingan nasional yang harus dilindungi sebagai sebuah keniscayaan. Demikian pula dengan putusan ICJ dalam kasus Sipadan - Ligitan tidak semata-mata berlandaskan prinsip 'effective occupation', tetapi dalam berbagai argumentasi atau pertimbangan hukumnya terkesan adanya kepentingan nasional negeri kincir angin di balik keputusan ICJ.

Perusahaan Shell yang sudah mendapat konsesi eksplorasi migas di wilayah Ambalat pasca Sipadan-Ligitan, di mana mayoritas saham perusahaan ini dimiliki Royal Dutch. Di samping itu, berbagai kerjasama bisnis, perdagangan dan investasi antara negara Nederland dan Malaysia diketahui telah terjalin sejak lama sehingga faktor-faktor seperti ini sulit untuk tidak mengatakan membawa pengaruh terhadap putusan ICJ yang memutuskan negeri tetangga sebagai pemilik atas pulau Sipadan dan Ligitan yang kini menjadi destinasi wisata termahal di dunia. Putusannya memang menerapkan prinsip 'effective occupation' sebagai cara untuk mendapatkan kedaulatan atas kedua pulau tersebut, namun kemenangan Malaysia atas Indonesia tidak bisa dikaji dari pendekatan yuridis semata-mata karena bagaimanapun pendekatan non-yuridis dan subjektif di balik kemenangan tersebut adalah sesuatu yang sulit terelakkan. 


\section{PENUTUP}

Dari berbagai macam cara dalam memperoleh kedaulatan teritorial, seperti cession, conquest atau annexation, discovery, operations of nature, occupation dan lainlain, maka semuanya dapat saja terjadi dan dilakukan dengan tujuan untuk menegaskan ataupun menciptakan hak (title) bagi suatu negara untuk memiliki dan menguasai wilayah yang bersangkutan. Penguasaan suatu wilayah dapat dinamakan sebagai penguasaan yang dilakukan berdasar asas efektivitas atau penguasaan efektif apabila negara yang bersangkutan mempunyai niat atau maksud (intention) dan menjalankan penguasaan secara nyata, berlangsung secara terus menerus dan damai tanpa mendapat kecaman dari negara-negara lain.

Penguasaan seperti itu dimaknai tidak hanya sebagai penguasaan secara fisik semata-mata, tetapi juga dan terutama sebagai penguasaan yang bersifat administratif dalam bentuk menjalankan fungsi-fungsi administrasi pemerintahan atas wilayah yang bersangkutan (effective occupation) serta mendapat pengakuan dari negara-ne gara lain, sehingga dengan demikian pelaksanaan fungsi-fungsi tersebut menciptakan hak (title) bagi negara yang bersangkutan.

Kasus Sipadan-Ligitan memperlihatkan bahwa negara tetangga yang sering menyebut dirinya sebagai negara serumpun oleh mahkamah internasional dinilai berhasil mendapatkan hak atas kedua pulau karena negara tersebut dan pendahulunya (United Kingdom) berhasil menjalankan fungsifungsi administrasi pemerintahan pada kedua pulau tersebut. Pemberlakuan beberapa peraturan pada zaman kolonial Inggris, seperti
Ordonansi 1934 mengenai pungutan retribusi terkait pengambilan telur-telur penyu yang terdapat di pulau Sipadan, demikian pula Ordonansi 1935 mengenai masalah ekologi guna memberi perlindungan terhadap satwa burung yang terdapat di sana. Selanjutnya, pemasangan instalasi mercusuar di lepas pantai Sipadan dan Ligitan demi menjamin keselamatan pelayaran, bagi mahkamah semuanya ini memiliki karakter legislasi yang bersangkutpaut dengan berjalannya fungsifungsi administrasi pemerintahan atas kedua pulau tersebut sehingga membuktikan adanya 'effective occupation' yang menciptakan hak bagi negara Malaysia atas kedua pulau tersebut.

Munculnya semacam pemikiran bahwa putusan ICJ dalam sengketa kepemilikan pulau Sipadan-Ligitan tidak semata-mata merupakan putusan yang bersifat yuridis adalah sesuatu yang wajar dan tidak dapat dielakkan. Adanya unsur-unsur eksternal yang mempengaruhi dan mewarnai keputusan mahkamah terkait kasus tersebut dapat dicermati dari berbagai argumentasi dan pertimbangan hukum yang sebenarnya hanya merupakan manifestasi dari permainan alibi dan silat lidah yang berlangsung dalam persidangan mahkamah. Hal ini disebabkan karena argumentasi dan pertimbangan hukumnya yang secara tersirat berfokus pada upaya terselubung untuk melindungi kepentingan negara tertentu, khususnya kepentingan ekonomi dan bisnisnya di negara tetangga.

Demi menghindari terjadinya perbedaan penafsiran mengenai cara memperoleh kedaulatan teritorial, maka berbagai macam cara akuisisi seharusnya mendapat 
perhatian dari semua negara karena tidak semua cara seperti itu dapat diakui sebagai suatu cara atau pendekatan yang dapat menciptakan hak yang sah (legal title). Kasus pulau Sipadan dan pulau Ligitan yang telah beralih kepemilikan sudah seharusnya menjadi kasus terakhir terkait lepasnya hak dan kedaulatan Indonesia atas suatu wilayah sehingga kasus seperti itu seharusnya dapat menjadi pelajaran berharga bagi semua elemen bangsa dalam menjaga dan melindungi keutuhan teritorial NKRI berbasis kesejahteraan rakyat sebagaimana amanat Pasal 33 UUD NRI 1945. Pemerintah Indonesia seharusnya menjalankan pengendalian efektif dalam menjaga pulau-pulau terluar yang berbasis pada langkah-langkah perwujudan kesejahteraan rakyat, agar tidak terulang kembali kasus Sipadan-Ligitan jilid-jilid beikutnya.

\section{BIBLIOGRAFI}

Akehurst, Michael. (1983). A Modern Introduction to International Law. Fourth Edition. London: George Allen and Unwin.

Beckman, Robert. (2009). "Moving Beyond Disputes Over Island Sovereignty:ICJ Decision Sets Stage for Maritime Boundary Delimitation in the Singapore Strait", Ocean Development \& International Law, 40:1-35, 2009 Copyright (CTaylor \& Francis Group.

Brownlie, Ian. (1979). Principles of Public International Law, Oxford: Oxford University Press.
Gautama, Soedargo. (1985). Soal-soal Aktual Hukum Perdata Internasional, Bandung: Binacipta.

Hudson, Manly O. (1951). International Law, Cases and Other Materials on International Law, Third Edition, St. Paul Minn, West Publishing \& Co.

International Court of Justice (ICJ) Reports. (2002). Sovereignty over Pulau Ligitan and Pulau Sipadan (Indonesia/Malaysia), Judgment of 17 December 2002.

Noor, S.M. (2008), Politik Hukum dalam Praktek Ratifikasi di Indonesia, (Disertasi). Makassar: Program Pascasarjana Universitas Hasanuddin.

Oegroseno, Arif Havas. (2009). "Status Hukum Pulau-Pulau Terluar Indonesia", Indonesian Journal of International Law, 6(3) April 2009.

Ott, David H. (1987), Public International Law in the Modern World, London: Pitman Publishing.

Parthiana, Wayan. (1981). "Perjanjian Internasional tak tertulis dalam Hukum Perjanjian Internasional", Jurnal Hukum dan Pembangunan, 11(4) Juli 1981.

Prescott, Victor and Schofield, Clive. (2005). The Maritime Political Boundaries of the World (Second Edition), Leiden/ Boston: Martinus Nijhoff Publishers.

Shaw, Malcolm N. (1986). International Law. Cambridge, Grotius Publications Limited.

Starke, J.G. (1984). Introduction to International Law. London: Butter-worths. 